\title{
Laboratory results of a 3rd generation roof bolter canopy air curtain for respirable coal mine dust control
}

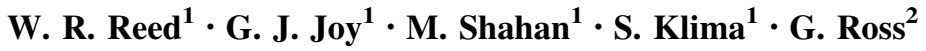

Received: 12 October 2018/Revised: 12 December 2018/Accepted: 12 January 2019/Published online: 23 January 2019

(C) The Author(s) 2019

\begin{abstract}
Testing was completed on an earlier roof bolter CAC that used slots to provide a perimeter airflow. NIOSH tested it due to its unique design that differed from canopies that provided uniform airflow. Based upon NIOSH recommendations from the earlier testing, a 3rd generation roof bolter CAC has been developed by J.H. Fletcher \& Co. The changes to this CAC involve design modifications to the plenum outlets, using a single row of outlets on the perimeter and a different material for the plenum. This laboratory testing was a continuation of the original perimeter slotted CAC design. Using gravimetric and instantaneous sampling of respirable dust concentrations underneath and outside of the CAC, the laboratory testing was completed using three different blower fans that delivered differing airflows. The maximum plenum airflow velocities ranged from 2.34 to $3.64 \mathrm{~m} / \mathrm{s}$ (460-716 fpm). Results showed plenum respirable dust concentrations ranging from $34.6 \%$ to $49.3 \%$ lower than respirable dust concentrations outside the plenum protection zone, thus showing an improvement in protection for the roof bolter operators.
\end{abstract}

Keywords Roof bolter $\cdot$ Respirable dust · Canopy air curtain $\cdot$ Coal mining

\section{Introduction}

Based on recent statistics in the U.S., following a low point in the late 1990s where the prevalence of coal workers' pneumoconiosis (CWP) in miners with 25 years or more tenure was approximately $5 \%$, CWP now exceeds $10 \%$ for miners with 25 years or more of tenure. In central

The findings and conclusions in this paper are those of the authors and do not necessarily represent the official position of the National Institute for Occupational Safety and Health, Centers for Disease Control and Prevention. Mention of company names or products does not constitute endorsement by NIOSH.

\section{W. R. Reed}

rreed@cdc.gov

1 Centers for Disease Control and Prevention, National Institute for Occupational Safety and Health, 626 Cochrans Mill Rd., Pittsburgh, PA 15236, USA

2 J.H Fletcher \& Co., Inc., 402 High St., Huntington, WV 25705, USA
Appalachia (Kentucky, Virginia, West Virginia), 20.6\% of long-tenured miners have CWP and $4.5 \%$ have progressive massive fibrosis, the most severe form of CWP (Blackley et al. 2018a). Additionally, NIOSH has reported on clusters of CWP at local clinics in Kentucky (60 miners) and Virginia (416 miners) (Blackley et al. 2016, 2018b). As deeper and thinner coal seams are mined today, there is the potential for more serious health problems which can be caused by respirable silica dust.

Canopy air curtains installed on roof bolters have become popular as a dust control device ever since the U.S. Federal Government reduced the coal mine respirable dust limit from 2.0 to $1.5 \mathrm{mg} / \mathrm{m}^{3}$, (Code of Federal Regulations, CFR 70.100 2015). The roof bolter canopy air curtain (CAC) uses a blower to provide filtered air over the roof bolter operator's normal work position. This filtered air provides protection against overexposure to coal mine respirable dust, which may cause coal workers' pneumoconiosis (CWP) or black lung, an occupational respiratory disease that has no cure and may ultimately be fatal (Newman 2014). 
The National Institute for Occupational Safety and Health (NIOSH) has completed several laboratory studies of the CAC, demonstrating its effectiveness for protection against overexposure to respirable coal mine dust with dust control efficiencies ranging from $14 \%$ to $75 \%$ (Goodman and Organiscak 2001; Listak and Beck 2012; Reed et al. 2017). Testing to demonstrate performance of the CAC in underground mining situations has been limited, with the majority of the testing completed on continuous miners with dust control efficiencies ranging from $23 \%$ to $69 \%$ (Krisko 1975; Listak and Beck 2012).

Researchers from the National Coal Board, Mining Research and Development Establishment conducted several field studies on the CAC that was installed on a Dosco Mk II boom-type heading machine. Their CAC design was similar to the CAC tested by NIOSH. In the machine tested, the operator stands while operating the machine with the CAC positioned over the operator's location. Their results showed $35 \%$ to $68 \%$ reductions in dust in blowing ventilation and $40 \%$ to $87 \%$ reductions in exhausting ventilation (European Communities Commission 1981, 1983).

The last testing completed by NIOSH was for a CAC design which included a slotted perimeter which anticipated providing airflow to protect the roof bolter from exposure to coal mine respirable dust (Reed et al. 2017). This design was unique in that it provided perimeter slots around the roof bolter canopy to provide perimeter airflow which had not been previously evaluated. The lab test results of the early perimeter design CAC demonstrated the CAC provided only up to $24.5 \%$ reductions for roof bolter operator coal mine respirable dust exposure (Reed et al. 2017). These results indicated that there was an opportunity for improvement. Therefore, NIOSH provided recommendations to improve the perimeter design based upon the lab test results and CFD evaluation of the early perimeter design. These recommendations resulted in the development of the 2nd generation CAC, which was not lab tested, and the 3rd generation CAC.

J.H. Fletcher \& Co., which has approximately $90 \%$ market share of roof bolters in the U.S. coal mining industry, has developed five different canopy configurations of the 2nd generation CAC to fit its different dualboom roof bolter models. Figure 1 presents different versions of the 2nd generation CAC, showing the left-side CAC of each configuration.

The 2nd generation CAC was modified by splitting the intake airflows from the blower into two different separate airflow streams. One stream is directed to the center nozzles which provide a uniform airflow across the center of the plenum. The airflow emanating from the center nozzles have a velocity that is lower than that of the perimeter nozzles. The other stream is directed to the perimeter nozzles. This airflow leaving the perimeter has a higher velocity than the velocity from the center nozzles. The perimeter nozzles are spaced using a staggered pattern, a design change recommended by NIOSH, which prevents contaminated outside air from infiltrating the uniform center clean airflow. As a continuation of the perimeter airflow design laboratory testing, The NIOSH laboratory evaluation examined a new 3rd generation CAC design by J.H. Fletcher \& Co. This is the CAC design that is currently being marketed to industry. The shape of the canopy/plenum is shown in Fig. 2. This new design (3rd generation) is an improvement on the 2nd generation CAC. It still maintains the two separate streams of intake airflow, but consists of a single row of perimeter nozzles surrounding a center pattern of holes. The perimeter and center holes are designed to provide different airflow velocities from their separate airflow splits. The perimeter holes contain nozzles that are redesigned to provide higher airflow velocities and a wider airflow dispersion from the outlet. They are situated such that their airflow prevents dust-contaminated air from entering the protection zone inside the perimeter. The center holes are designed to provide lower uniform airflow velocities across the area within the high airflow perimeter. The specifications for the plenum openings are listed in Table 1 . The other redesign was to construct the plenum plate of aluminum to reduce the weight of the canopy. The 2nd generation was constructed entirely of steel. These 3rd generation improvements allow for simpler manufacturing of the roof bolter CAC providing better distribution to the underground coal mining industry.

Laboratory testing of the 2nd generation CAC was not completed. While it is still used at some locations, the 2nd generation $\mathrm{CAC}$ was short lived and was quickly replaced with the 3rd generation designed CAC.

\section{Test procedure}

Testing of the 3rd generation CAC was conducted in two phases. The first phase measured the velocity profile of the air distribution from the plenum. The second phase tested the effectiveness of the CAC for respirable dust control. Each phase utilized three different types of blowers, Small Fan \#1 and Medium Fan \#2 were hydraulically driven. Large Fan 3 was an electrically driven blower. Specifications of the blowers are provided in Table 2. Each blower used a filter to provide clean air to the plenum. The same intake filter was used for each fan. The specifications for the filter are listed in Table 3. 

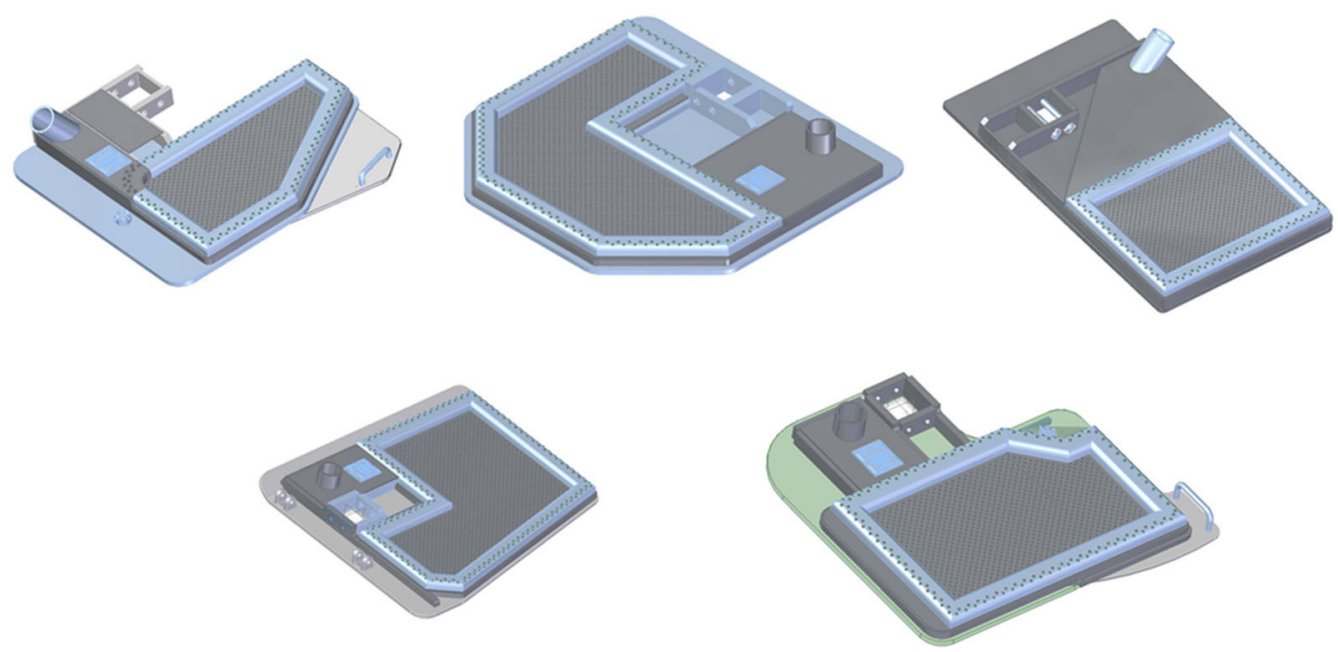

Fig. 1 Different 2nd generation CAC designs developed by J.H. Fletcher \& Co. for different roof bolter models. These are all models showing the left-side CAC. The upper left model was previously field tested by NIOSH

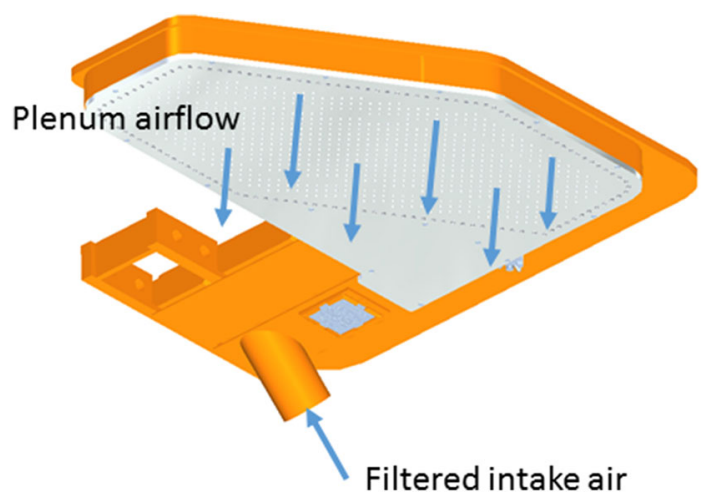

Fig. 2 3rd generation roof bolter canopy design with the new plenum design

\subsection{Air velocity measurement}

This phase of the testing determined the air velocity profile of the CAC. A test stand was built to support the CAC. A $10.2-\mathrm{cm}$ by $10.2-\mathrm{cm}$ (4-in by 4 -in.) grid was placed $25.4 \mathrm{~cm}$ (10 in.) below the plenum face. The measurement grid extended approximately $30.5 \mathrm{~cm}$ (12 in.) beyond the

Table 1 Specifications of the plate openings used in Fletcher canopy air curtain

\begin{tabular}{ll}
\hline 3rd generation CAC design \\
\hline Opening type & Round holes \\
Opening & Perimeter: $129 @ 4.75 \mathrm{~mm}$ diameter \\
dimensions & $(0.1875$ in. $)$ \\
& Center: $829 @ 6.35 \mathrm{~mm}$ diameter $(0.25$ in. $)$ \\
Open area & $\approx 7.30 \%$ \\
Total plenum area & $3890 \mathrm{~cm}^{2}\left(603 \mathrm{in.}^{2}\right)$ \\
\hline
\end{tabular}

${ }^{\mathrm{a}}$ Number of holes determined from JH Fletcher Drawing 569664 perimeter of the CAC. The test stand and measurement procedure has been described in previous literature (Listak and Beck 2012; Reed et al. 2017).

Each blower was attached to the CAC using flexible hose to produce the airflow through the CAC. Measurements were made using the maximum supply air volume that was provided by the blower. The supply air volume was calculated using a single-point pitot tube measurement in a straight rigid section of the air supply system. Measurements of the resultant canopy plenum airflow were made at the center of each grid location using a hotwire anemometer. The grid measurements were done in triplicate and averaged to produce a velocity profile of the plenum. Velocity measurements were made for each blower setup (i.e., Small Fan \#1, Medium Fan \#2, and Large Fan \#3).

\subsection{Respirable dust control effectiveness}

The CAC was tested to evaluate its performance as a respirable dust control. This testing was performed at NIOSH's Pittsburgh Mining Research Division. An airway corridor was constructed $1.96 \mathrm{~m}$ (77 in.) high by $2.87 \mathrm{~m}$ (113 in.) wide by $8.61 \mathrm{~m}$ (339 in.) long. The CAC was centered in the corridor and bolted directly to the $1.96-\mathrm{m}$ (77-in.) high ceiling. It was located approximately $2.54 \mathrm{~m}$ (100 in.) from the end of the corridor. The dust feeder was placed approximately $5.08 \mathrm{~m}$ (200 in.) upwind of the CAC, and the airborne dust had to make a U-turn to reach the CAC location (Fig. 3). This setup was used to maximize mixing of the airborne dust with the ventilation airflow. The coal dust used for testing was a fine-sized coal dust, Keystone Black (325BA Mineral Black Filler). 


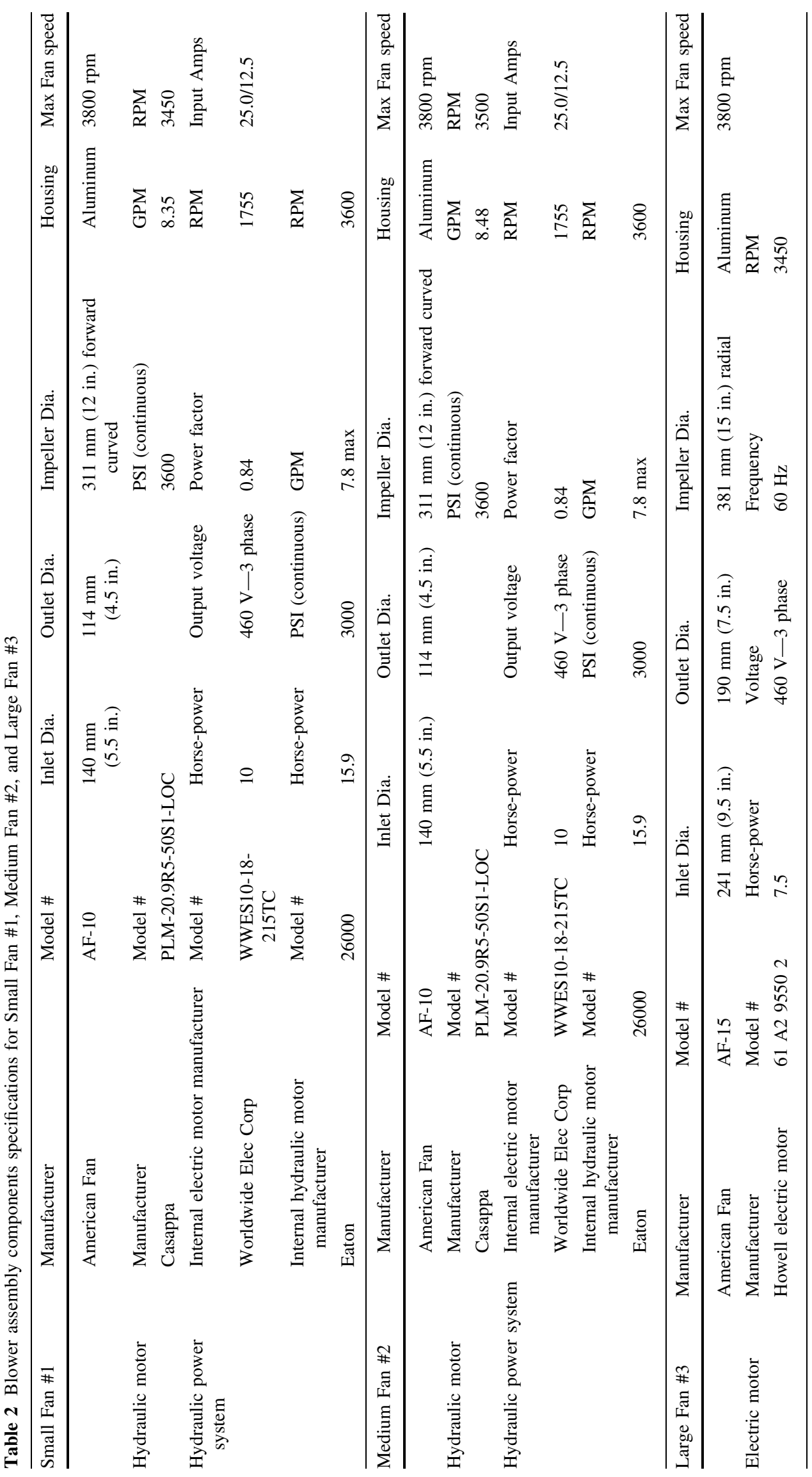


Table 3 Filter specifications

\begin{tabular}{llllll}
\hline Manufacturer & Filter \# & Outer Dia. & Inner Dia. & Height & Efficiency \\
\hline American air filter & Red Clean N & $324 \mathrm{~mm} \mathrm{(12.75} \mathrm{in.)}$ & $244 \mathrm{~mm} \mathrm{(8.625} \mathrm{in.)}$ & 318 mm (12.5 in.) & Merv 15 \\
\hline
\end{tabular}

\subsubsection{Sampling method}

Both gravimetric and instantaneous samplers were used for testing the CAC. The gravimetric samplers consisted of 10-mm Dorr-Oliver cyclones and 37-mm 5- $\mu \mathrm{m}$ PVC filters with a sampling airflow of $2.0 \mathrm{~L} / \mathrm{min}$ regulated by individual critical orifices. The instantaneous samplers were Thermo Scientific personal DataRAM 1000 (pDR-1000) nephelometers.

A sampling package comprised of two gravimetric and one instantaneous sampler (pDR-1000) was used to sample respirable dust at a location $1.52 \mathrm{~m}(5 \mathrm{ft})$ upstream of the

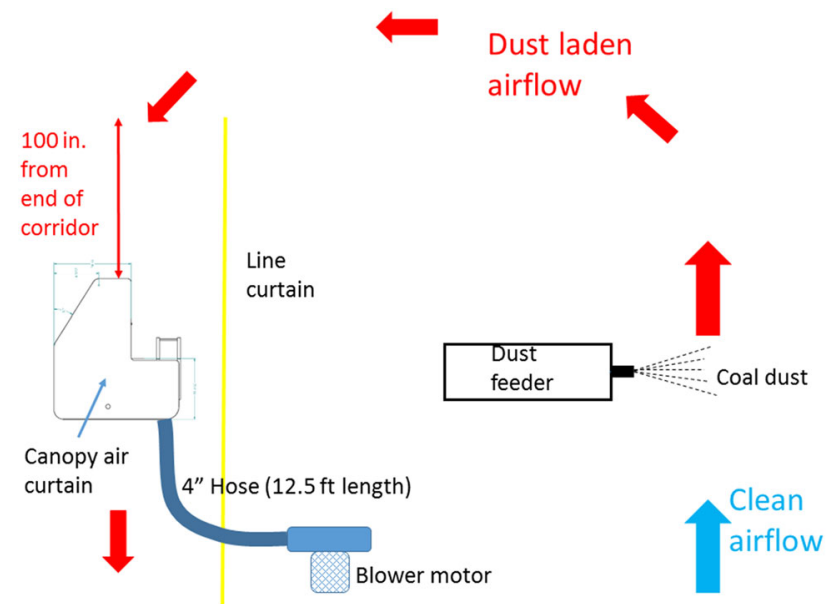

Fig. 3 Layout of the CAC testing in the continuous miner gallery

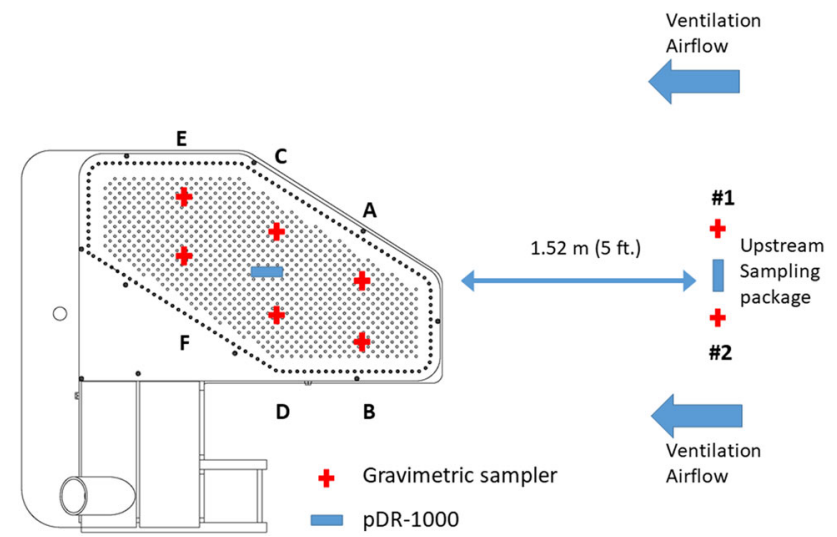

Fig. 4 Gravimetric filter and pDR locations below the CAC (sampling locations are approximate), including upstream sampling location. Large blue arrows depict ventilation airflow
CAC. These samplers were set to a height that was $25.4 \mathrm{~cm}$ (10 in.) below the plenum. This sampling package was used to monitor the respirable upstream dust concentration, which served as the baseline condition, throughout the test. The gravimetric samplers of this upstream sampling package were labeled as upstream \#1 and \#2 (Fig. 4).

Underneath the CAC, a pDR-1000 sampler and six gravimetric samplers were placed within the plenum outflow. These samplers were located $25.4 \mathrm{~cm}$ (10 in.) below the plenum and were used to monitor the respirable dust concentrations underneath the CAC (Fig. 4). These six gravimetric samplers were labeled A, B, C, D, E, and F.

A pDR sampler was placed downstream $1.52 \mathrm{~m}(5 \mathrm{ft})$ from the CAC test stand and also in the center of the entry at a height equivalent to $25.4 \mathrm{~cm}$ (10 in.) below the plenum. The purpose of this pDR downstream sampler was solely to monitor the dust conditions in the test facility. This sampler was not used in the analysis of this study.

\subsubsection{Test procedure}

Nominal ventilation air velocities of $0.3 \mathrm{~m} / \mathrm{s}(60 \mathrm{fpm})$ and $0.6 \mathrm{~m} / \mathrm{s}(120 \mathrm{fpm})$ were the two different ventilation airflow conditions that were evaluated during testing, The ventilation air velocities were measured in the section where the CAC test stand was located. The orientation of the CAC to the ventilation airflow is shown in Fig. 3, with the plenum airflow directed downward. The velocities in the entry were verified prior to and after testing using a hotwire anemometer. A dust feeder introduced dust into a pressurized airflow stream through a conduit system with a 2.5-cm (1-in.) diameter outlet and then into the entry to obtain an upwind respirable dust concentration of approximately $6.0 \mathrm{mg} / \mathrm{m}^{3}$. This target concentration was selected because previous NIOSH studies have shown that this level of dust is encountered in the return of continuous miners using scrubbers (Listak and Beck 2012; Colinet et al. 2013; Potts et al. 2011). Due to the configuration of the test facility, dust generation capability, and differing daily air properties, a range of target concentrations was encountered $\left(2.4-13.2 \mathrm{mg} / \mathrm{m}^{3}\right)$. The instantaneous samplers (pDR1000) were used to monitor dust concentrations during testing.

Following development of the test dust concentration, the evaluation proceeded by testing the CAC with the air supply blower off (baseline condition) and then testing 
Table 4 Airflow statistics for canopy air curtain

\begin{tabular}{llll}
\hline Fan & Height underneath canopy (cmlin.) & Maximum airflow velocity $(\mathrm{m} / \mathrm{s} / \mathrm{fpm})$ & Airflow quantity supplied $\left(\mathrm{m}^{3} / \mathrm{s} / \mathrm{cfm}\right)$ \\
\hline Small Fan \#1 & 25.4110 & 2.341460 & $0.170 \mid 361$ \\
Medium Fan \#2 & 25.4110 & 2.661524 & $0.175 \mid 370$ \\
Large Fan \#3 & 25.4110 & 3.641716 & $0.213 \mid 452$ \\
\hline
\end{tabular}

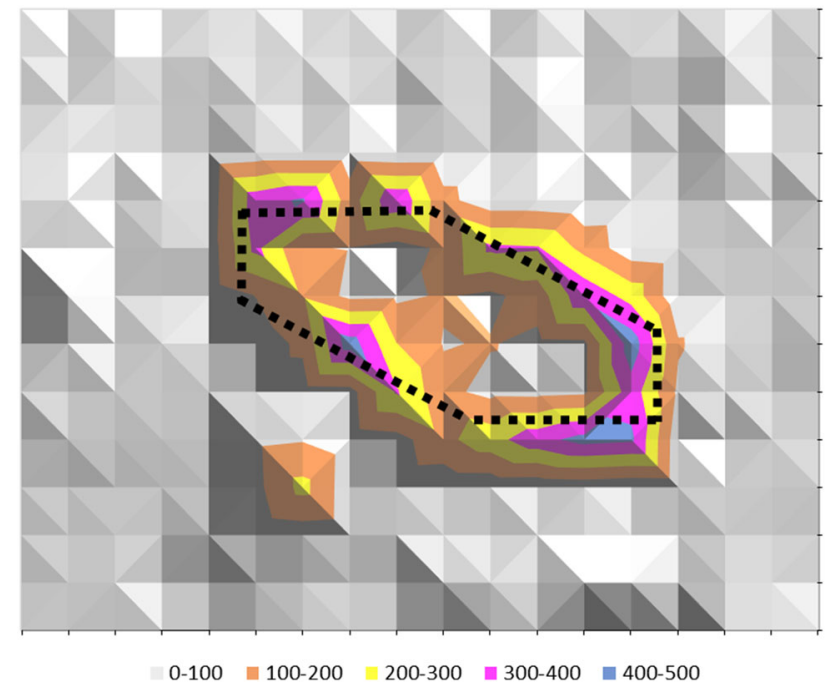

Fig. 5 Airflow velocities (ft./min) at 10-in. height underneath the canopy air curtain using Small Fan $\# 1 \approx 0.170 \mathrm{~m}^{3} / \mathrm{s}(360 \mathrm{cfm})$. The black dashed line represents the perimeter nozzles of the CAC

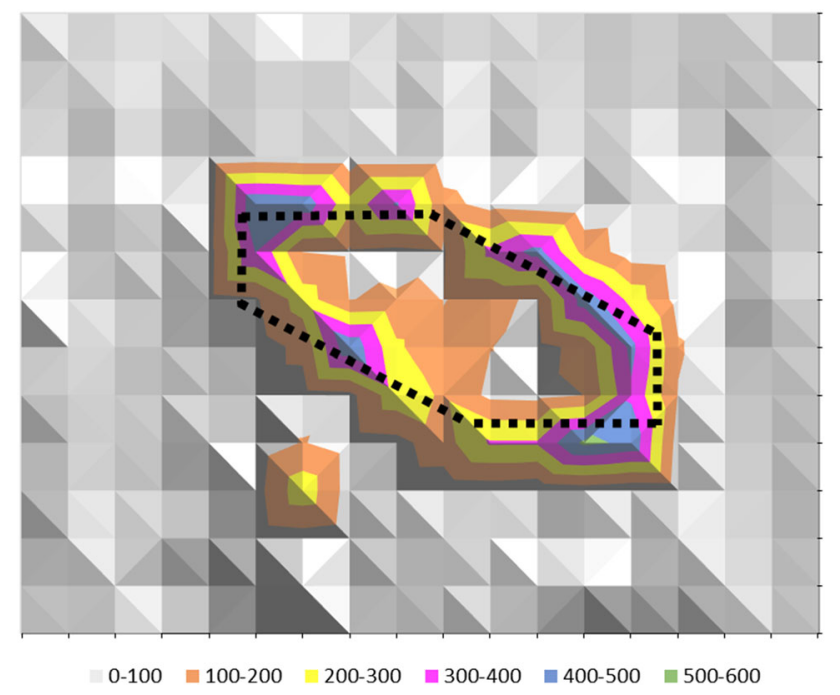

Fig. 6 Airflow velocities (ft./min) at 10-in. height underneath the canopy air curtain using Medium Fan $\# 2 \approx 0.175 \mathrm{~m}^{3} / \mathrm{s}(370 \mathrm{cfm})$. The black dashed line represents the perimeter nozzles of the CAC

with the air supply blower turned on (test condition). Dust concentrations were measured for $30 \mathrm{~min}$ in each condition. Using a statistical method for sample size determination described in "Experimental Statistics" (Natrella

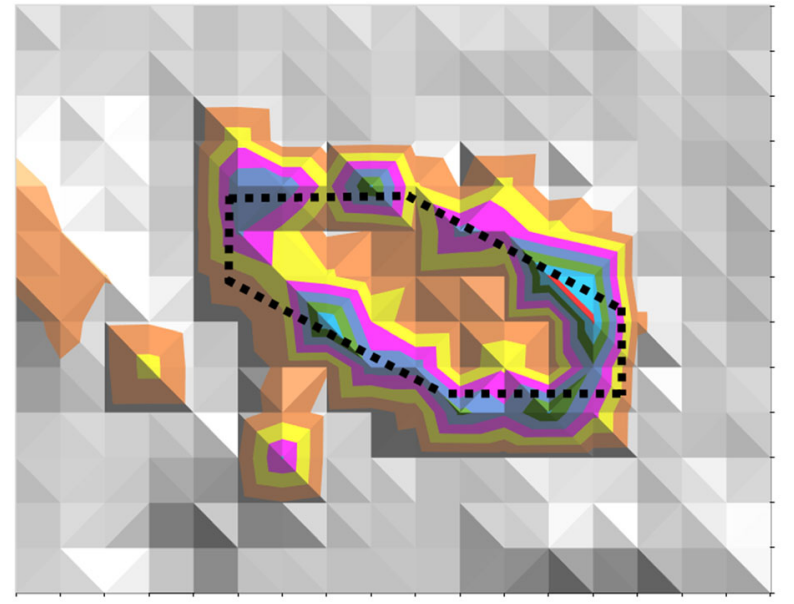

$0-100=100-200=200-300=300-400=400-500=500-600=600-700 \backsim 700-800$

Fig. 7 Airflow velocities (ft./min) at 10-in. height underneath the canopy air curtain using Large Fan $\# 3 \approx 0.212 \mathrm{~m}^{3} / \mathrm{s}$ (450 cfm). The black dashed line represents the perimeter nozzles of the CAC

1963), it was determined that 3-5 trials were required for each test.

\section{Air velocity results}

Table 4 presents plenum airflow velocity information for each blower. Air velocity profiles are presented in Figs. 5, 6 , and 7 . The maximum airflow from the plenum ranged from 2.34 to $3.64 \mathrm{~m} / \mathrm{s}$ (460-716 fpm). It was observed that there was an area of low velocity inside the perimeter nozzles. Also, the low velocities ranged from 0.25 to $0.51 \mathrm{~m} / \mathrm{s}(50-100 \mathrm{fpm})$ with an airflow direction from the ground up to the plenum, instead of the expected plenum to ground direction. This upward airflow pattern could have a negative effect on CAC performance. This phenomenon was minimized when a larger fan was used to supply a higher amount of air to the plenum.

\section{Dust control effectiveness results}

Due to the variation of target dust concentration between tests (2.4 to $13.2 \mathrm{mg} / \mathrm{m}^{3}$ ), direct comparisons of the gravimetric concentrations was not suitable because the 
goal was not to compare the dust reductions due to variations in the target concentration. The goal was to compare the results due to "canopy on" and "canopy off" conditions. Therefore, the ratio of the average of the six undercanopy gravimetric samplers to the average of the two upwind gravimetric samplers was used to assess the effectiveness of the CAC. The ratio comparison minimizes the impact of varying target concentrations on dust reductions. The upwind gravimetric samplers were designated \#1 and \#2, and the under-canopy gravimetric samplers were designated $\mathrm{A}$ through $\mathrm{F}$. Therefore, the ratio determined for each test condition (canopy blower on) and each baseline condition (canopy blower off) was (Reed et al. 2017): ratio $=\frac{(A+B+C+D+E+F) / 6}{(\# 1+\# 2) / 2}$

where $A$ through $F$ are respirable dust masses (mg) collected by the six under-canopy gravimetric samplers, and $\# 1$ and \#2 are respirable dust masses (mg) collected by the two upwind gravimetric samplers. Eqs. (1) and (2) are equivalent.

ratio $=\frac{\text { canopy }}{\text { upwind }}$

where canopy $=$ the average of the six respirable dust concentrations $(\mathrm{A}-\mathrm{F})$ underneath the canopy, upwind $=$ the average of the two upwind respirable dust concentrations (1 and 2).

Table 5 Test data results for CAC at 10-in. height underneath the canopy using Small Fan \#1

\begin{tabular}{|c|c|c|c|c|c|c|c|c|c|c|c|}
\hline $\begin{array}{l}\text { Test } \\
\text { no. }\end{array}$ & $\begin{array}{l}\text { Airflow } \\
\text { velocity (m/ } \\
\text { slfpm) }\end{array}$ & $\begin{array}{l}\text { Canopy- } \\
\text { off/-on }\end{array}$ & $\begin{array}{l}\text { Fan } \\
\text { airflow } \\
\left(\mathrm{m}^{3} / \mathrm{slcfm}\right)\end{array}$ & $\begin{array}{l}\text { Upwind } \\
1(\mathrm{mg} / \\
\left.\mathrm{m}^{3}\right)\end{array}$ & $\begin{array}{l}\text { Upwind } \\
2(\mathrm{mg} / \\
\left.\mathrm{m}^{3}\right)\end{array}$ & $\begin{array}{l}\text { Canopy } \\
\text { A (mg/ } \\
\left.\mathrm{m}^{3}\right)\end{array}$ & $\begin{array}{l}\text { Canopy } \\
\text { B (mg/ } \\
\left.\mathrm{m}^{3}\right)\end{array}$ & $\begin{array}{l}\text { Canopy } \\
\mathrm{C}(\mathrm{mg} / \\
\left.\mathrm{m}^{3}\right)\end{array}$ & $\begin{array}{l}\text { Canopy } \\
\mathrm{D}(\mathrm{mg} / \\
\left.\mathrm{m}^{3}\right)\end{array}$ & $\begin{array}{l}\text { Canopy } \\
\text { E (mg/ } \\
\left.\mathrm{m}^{3}\right)\end{array}$ & $\begin{array}{l}\text { Canopy } \\
\mathrm{F}(\mathrm{mg} / \\
\left.\mathrm{m}^{3}\right)\end{array}$ \\
\hline $1060-1$ & 0.33165 & Off & $0.162 \mid 343$ & 6.783 & 6.717 & 6.667 & 6.500 & 6.750 & 6.433 & 6.200 & 6.567 \\
\hline $1060-2$ & 0.36170 & Off & $0.160 \mid 339$ & 9.917 & 9.800 & 9.117 & 9.000 & 8.317 & 8.983 & 8.450 & 8.750 \\
\hline $1060-3$ & 0.28156 & Off & $0.166 \mid 351$ & 10.083 & 10.450 & 9.000 & 9.000 & 8.767 & 8.650 & 8.117 & 8.867 \\
\hline $1060-4$ & 0.32163 & Off & $0.172 \mid 365$ & 8.767 & 8.533 & 8.033 & 8.050 & 8.117 & 8.350 & 7.350 & 8.033 \\
\hline $1060-5$ & 0.27153 & Off & $0.171 \mid 362$ & 8.167 & 8.300 & 8.333 & 8.183 & 8.017 & 7.600 & 7.933 & N/A \\
\hline $1060-1$ & 0.36171 & On & $0.162 \mid 343$ & 9.283 & 9.317 & 5.517 & 4.850 & 4.633 & 3.317 & 5.033 & 5.667 \\
\hline $1060-2$ & $0.25 \mid 50$ & On & $0.160 \mid 339$ & 10.200 & 10.167 & 6.383 & 5.600 & 4.833 & 4.083 & 5.450 & 5.800 \\
\hline $1060-3$ & 0.32162 & On & $0.166 \mid 351$ & 10.050 & 10.267 & 6.200 & 5.217 & 4.850 & 2.900 & 5.367 & 5.833 \\
\hline $1060-4$ & 0.31161 & On & $0.172 \mid 365$ & 8.800 & 9.650 & 5.517 & 4.900 & 4.833 & 3.733 & 5.183 & 5.750 \\
\hline $1060-5$ & 0.32164 & On & $0.171 \mid 362$ & 9.317 & 9.967 & 1.800 & 4.833 & 4.683 & 3.733 & 5.733 & 6.783 \\
\hline $\begin{array}{l}10120- \\
6\end{array}$ & $0.64 \mid 127$ & Off & $0.166 \mid 352$ & 5.850 & 5.917 & 5.567 & 5.483 & 5.800 & 5.233 & 5.650 & 5.950 \\
\hline $\begin{array}{l}10120- \\
7\end{array}$ & $0.63 \mid 124$ & Off & $0.158 \mid 334$ & 9.000 & 9.583 & 9.317 & 9.533 & 9.733 & 9.200 & 9.400 & 9.383 \\
\hline $\begin{array}{c}10120- \\
8\end{array}$ & $0.61 \mid 120$ & Off & $0.153 \mid 325$ & 8.917 & 9.017 & 8.233 & 8.717 & 9.117 & 8.900 & 9.367 & 9.267 \\
\hline $\begin{array}{l}10120- \\
9\end{array}$ & $0.62 \mid 123$ & Off & $0.165 \mid 349$ & 13.283 & 11.650 & 9.900 & 10.917 & 10.700 & 10.917 & 10.700 & 10.767 \\
\hline $\begin{array}{c}10120- \\
10\end{array}$ & $0.60 \mid 119$ & Off & $0.165 \mid 349$ & 10.117 & 11.117 & 10.550 & 10.567 & 10.717 & 9.867 & 10.300 & 10.450 \\
\hline $\begin{array}{l}10120- \\
6\end{array}$ & $0.65 \mid 128$ & On & $0.166 \mid 352$ & 6.683 & 6.417 & 4.100 & 3.450 & 3.417 & 2.900 & 4.117 & 4.583 \\
\hline $\begin{array}{l}10120- \\
7\end{array}$ & $0.62 \mid 123$ & On & $0.158 \mid 334$ & 9.783 & 10.167 & 6.633 & 5.567 & 5.383 & 3.483 & 6.333 & 6.917 \\
\hline $\begin{array}{c}10120- \\
8\end{array}$ & $0.66 \mid 130$ & On & $0.153 \mid 325$ & 10.700 & 9.450 & 6.933 & 5.767 & 5.200 & 3.750 & 5.717 & 6.733 \\
\hline $\begin{array}{l}10120- \\
9\end{array}$ & $0.63 \mid 124$ & On & $0.165 \mid 349$ & 9.800 & 10.050 & 7.550 & 6.650 & 6.100 & 4.717 & 6.100 & 7.017 \\
\hline $\begin{array}{c}10120- \\
10\end{array}$ & $0.58 \mid 115$ & On & $0.165 \mid 349$ & 9.850 & 9.833 & 7.283 & 5.883 & 5.433 & 4.417 & 5.783 & 6.100 \\
\hline
\end{tabular}

$\mathrm{N} / \mathrm{A}=$ sample not available 
Table 6 Test data results for CAC at 10-in. height underneath the canopy using Medium Fan \#2

\begin{tabular}{|c|c|c|c|c|c|c|c|c|c|c|c|}
\hline $\begin{array}{l}\text { Test } \\
\text { no. }\end{array}$ & $\begin{array}{l}\text { Airflow } \\
\text { velocity (m/ } \\
\text { slfpm) }\end{array}$ & $\begin{array}{l}\text { Canopy- } \\
\text { off/-on }\end{array}$ & $\begin{array}{l}\text { Fan } \\
\text { airflow } \\
\left(\mathrm{m}^{3} / \mathrm{slcfm}\right)\end{array}$ & $\begin{array}{l}\text { Upwind } \\
1(\mathrm{mg} / \\
\left.\mathrm{m}^{3}\right)\end{array}$ & $\begin{array}{l}\text { Upwind } \\
2(\mathrm{mg} / \\
\left.\mathrm{m}^{3}\right)\end{array}$ & $\begin{array}{l}\text { Canopy } \\
\mathrm{A}(\mathrm{mg} / \\
\left.\mathrm{m}^{3}\right)\end{array}$ & $\begin{array}{l}\text { Canopy } \\
\text { B (mg/ } \\
\left.\mathrm{m}^{3}\right)\end{array}$ & $\begin{array}{l}\text { Canopy } \\
\mathrm{C}(\mathrm{mg} / \\
\left.\mathrm{m}^{3}\right)\end{array}$ & $\begin{array}{l}\text { Canopy } \\
\mathrm{D}(\mathrm{mg} / \\
\left.\mathrm{m}^{3}\right)\end{array}$ & $\begin{array}{l}\text { Canopy } \\
\text { E (mg/ } \\
\left.\mathrm{m}^{3}\right)\end{array}$ & $\begin{array}{l}\text { Canopy } \\
\mathrm{F}(\mathrm{mg} / \\
\left.\mathrm{m}^{3}\right)\end{array}$ \\
\hline $\begin{array}{c}1060- \\
11\end{array}$ & 0.37172 & Off & $0.188 \mid 399$ & 7.950 & 8.017 & 7.183 & 7.383 & 6.900 & 6.783 & 7.233 & 7.150 \\
\hline $\begin{array}{c}1060- \\
12\end{array}$ & $0.34 \mid 68$ & Off & $0.187 \mid 396$ & 9.767 & 9.233 & 8.400 & 8.800 & 7.617 & 8.650 & 7.950 & 7.883 \\
\hline $\begin{array}{c}1060- \\
13\end{array}$ & 0.25149 & Off & $0.186 \mid 395$ & 8.033 & 8.850 & 7.917 & N/A & 6.883 & 7.950 & 7.317 & 7.050 \\
\hline $\begin{array}{c}1060- \\
11\end{array}$ & 0.42182 & On & $0.188 \mid 399$ & 7.667 & 8.350 & 4.767 & 4.333 & 4.400 & 3.533 & 4.317 & 5.267 \\
\hline $\begin{array}{c}1060- \\
12\end{array}$ & 0.41180 & On & $0.187 \mid 396$ & 10.667 & 9.383 & 6.283 & 5.367 & 5.283 & 4.167 & 5.583 & 6.133 \\
\hline $\begin{array}{c}1060- \\
13\end{array}$ & 0.25149 & On & 0.1861395 & 8.367 & 7.633 & 4.767 & 4.033 & 3.800 & 2.483 & 4.583 & 5.183 \\
\hline $\begin{array}{c}10120- \\
14\end{array}$ & $0.63 \mid 124$ & Off & $0.181 \mid 383$ & 5.983 & 7.633 & 7.500 & 7.233 & 6.667 & 7.467 & 7.233 & 7.167 \\
\hline $\begin{array}{c}10120- \\
15\end{array}$ & $0.68 \mid 134$ & Off & $0.185 \mid 392$ & 6.083 & 6.200 & 5.283 & 6.050 & 5.750 & 5.950 & 5.917 & 6.000 \\
\hline $\begin{array}{c}10120- \\
16\end{array}$ & $0.57 \mid 112$ & Off & $0.186 \mid 394$ & 4.417 & 5.367 & 4.967 & 5.217 & 5.533 & 5.233 & 5.517 & 5.450 \\
\hline $\begin{array}{c}10120- \\
14\end{array}$ & $0.58 \mid 115$ & On & $0.181 \mid 383$ & 6.133 & 6.483 & 4.633 & 4.067 & 4.083 & 3.317 & 4.100 & 3.900 \\
\hline $\begin{array}{c}10120- \\
15\end{array}$ & $0.69 \mid 135$ & On & $0.185 \mid 392$ & 5.333 & 6.017 & 4.817 & 3.983 & 3.933 & 2.550 & 4.083 & 4.367 \\
\hline $\begin{array}{c}10120- \\
16\end{array}$ & $0.65 \mid 128$ & On & $0.186 \mid 394$ & 5.050 & 5.317 & 4.383 & 3.517 & 3.683 & 2.600 & 3.683 & 3.583 \\
\hline
\end{tabular}

$\mathrm{N} / \mathrm{A}=$ sample not available

The dust control efficiency was calculated by comparing the ratios from the canopy-on and canopy-off trials using the following equation:

efficiency $=\left(1-\left(\frac{\text { ratioon }}{\text { ratiooff }}\right)\right) \times 100$

where ratio on $=$ the ratio from the canopy-on trial, ratio off $=$ the ratio from the canopy-off trial.

Test data results are shown in Tables 5, 6, and 7. Statistical analysis was conducted using the Wilcoxson Rank Sum Test. This is a nonparametric statistical test that is selected because a determination of whether or not the data follows a normal distribution is not required. However, if the data follows a normal distribution, the Wilcoxson Rank Sum Test is a poorer quality test. Therefore, a statistical analysis using the $t$ test at $95 \%$ significance level was also conducted.

From the resultant data, ratios for the canopy-off and canopy-on scenarios were calculated using Eq. (1) or (2) and then were used for determining dust control efficiency using Eq. (3). The ratios are presented in Tables 8, 9, and 10 .
Dust control efficiencies were calculated from the ratios using Eq. (3), and the data sets were evaluated to determine if the averages from the canopy-off and canopy-on were statistically different. The Wilcoxson Rank Sum Test using a 95\% significance level was applied in this evaluation (Natrella 1963) with results presented in Tables 11, 12, and 13. In all cases, the results demonstrated that there was a statistically significant difference between the two data sets. The two tailed $t$ test was also completed on the data and demonstrated a statistically significant difference for all cases.

The average amount of air supplied to the plenum by each of the three different fans is shown in Table 14. From the test results, it can be seen that supplying a higher amount of airflow leads to better dust reductions. Supplying $0.231 \mathrm{~m}^{3} / \mathrm{s}$ (490 $\mathrm{cfm}$ ) average airflow resulted in a $49.3 \%$ reduction with a $0.3-\mathrm{m} / \mathrm{s} \quad(60-\mathrm{fpm})$ ventilation velocity and $43.6 \%$ with a $0.6-\mathrm{m} / \mathrm{s}(120-\mathrm{fpm})$ ventilation velocity. By comparison, at a $0.162-\mathrm{m}^{3} / \mathrm{s}(344-\mathrm{cfm})$ average airflow, dust reductions were $44.4 \%$ at $0.3 \mathrm{~m} / \mathrm{s}(60$ $\mathrm{fpm})$ ventilation velocity and $29.8 \%$ at $0.6 \mathrm{~m} / \mathrm{s}(120 \mathrm{fpm})$ ventilation velocity. The graphs presented in Figs. 8 and 9 


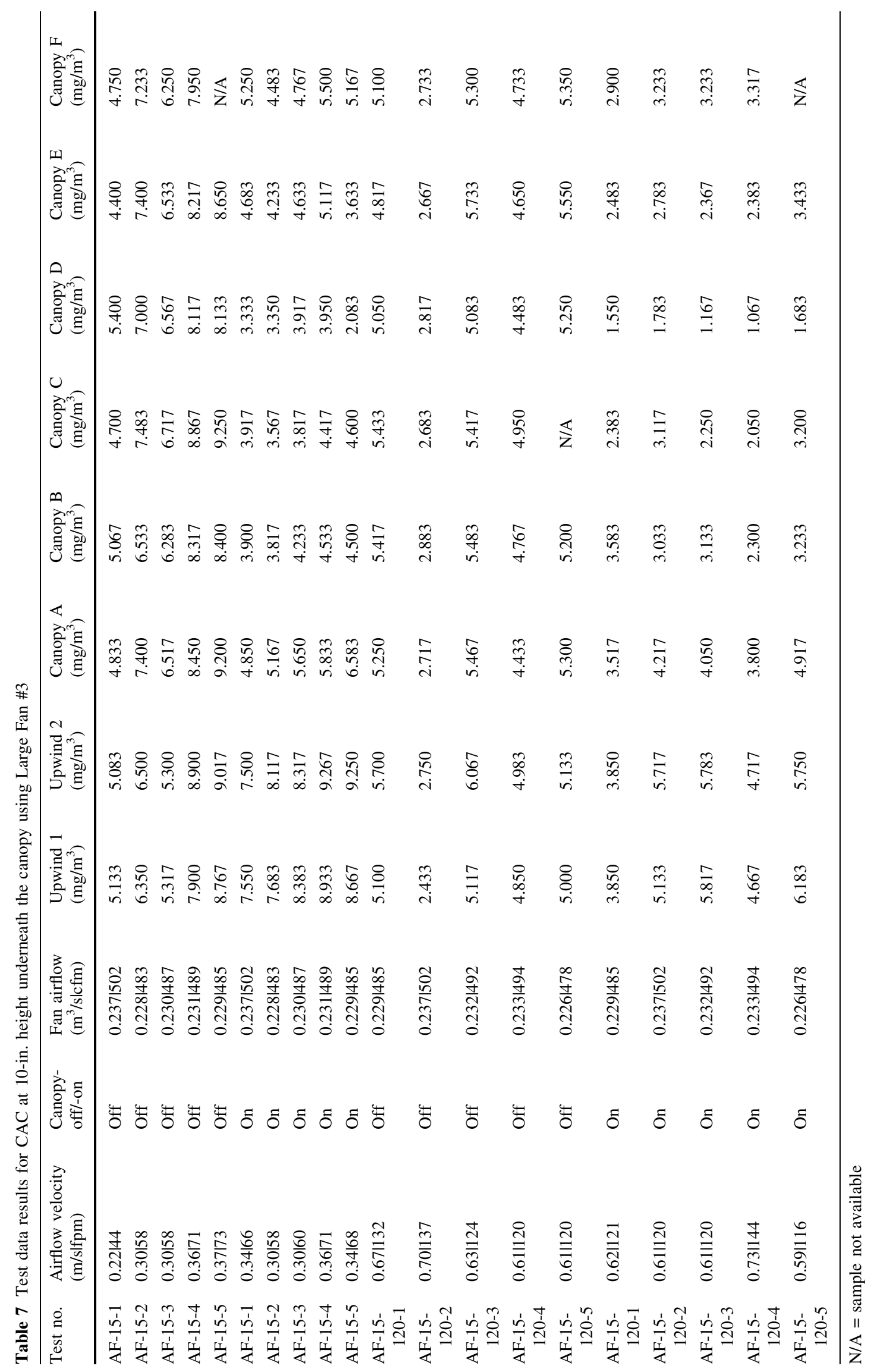


Table 8 Ratios calculated for the CAC at 10-in. height underneath the canopy using Small Fan \#1

\begin{tabular}{llllllllr}
\hline Canopy-off/-on & Airflow Velocity $(\mathrm{m} / \mathrm{slfpm})$ & Trial 1 & Trial 2 & Trial 3 & Trial 4 & Trial 5 & Average & SD \\
\hline Off & 0.30160 & 0.966 & 0.890 & 0.851 & 0.924 & 0.973 & 0.921 & 0.046 \\
On & 0.30160 & 0.520 & 0.526 & 0.498 & 0.540 & 0.477 & 0.512 & 0.022 \\
Off & 0.611120 & 1.006 & 0.979 & 1.028 & 0.924 & 0.940 & 0.975 & 0.039 \\
On & 0.611120 & 0.714 & 0.680 & 0.713 & 0.698 & 0.620 & 0.685 & 0.035 \\
\hline
\end{tabular}

Table 9 Ratios calculated for the CAC at 10-in. height underneath the canopy using Medium Fan \#2

\begin{tabular}{lllllrr}
\hline Canopy-off/-on & Airflow velocity $(\mathrm{m} / \mathrm{slfpm})$ & Trial 1 & Trial 2 & Trial 3 & Average & SD \\
\hline Off & 0.30160 & 0.890 & 0.865 & 0.879 & 0.878 & 0.010 \\
On & 0.30160 & 0.554 & 0.546 & 0.518 & 0.539 & 0.015 \\
Off & 0.611120 & 1.059 & 0.948 & 1.087 & 1.032 \\
On & 0.611120 & 0.637 & 0.697 & 0.690 & 0.674 \\
\hline
\end{tabular}

Table 10 Ratios calculated for the CAC at 10-in. height underneath the canopy using Large Fan \#3

\begin{tabular}{lllllllrr}
\hline Canopy-off/-on & Airflow velocity (m/slfpm) & Trial 1 & Trial 2 & Trial 3 & Trial 4 & Trial 5 & Average & SD \\
\hline Off & 0.30160 & 0.951 & 1.117 & 1.220 & 0.990 & 0.981 & 1.052 & 0.101 \\
On & 0.30160 & 0.574 & 0.519 & 0.539 & 0.538 & 0.494 & 0.533 & 0.026 \\
Off & 0.611120 & 0.959 & 1.061 & 0.968 & 0.950 & 1.052 & 0.998 & 0.048 \\
On & 0.611120 & 0.711 & 0.558 & 0.466 & 0.530 & 0.552 & 0.563 & 0.081 \\
\hline
\end{tabular}

Table 11 Summary of dust control efficiency for the CAC at 10-in. height underneath the canopy using Small Fan \#1

\begin{tabular}{lllllr}
\hline $\begin{array}{l}\text { Velocity } \\
(\mathrm{m} / \mathrm{s} \text { lfpm })\end{array}$ & $\begin{array}{l}\text { Average canopy-off ratio } \\
\text { (canopy/upwind) }\end{array}$ & $\begin{array}{l}\text { Average canopy-on ratio } \\
\text { (canopy/upwind) }\end{array}$ & $\begin{array}{l}\text { Dust } \\
\text { reduction } \\
(\%)\end{array}$ & $\begin{array}{l}\text { Statistically significant } \\
\text { (Wilcoxson rank sum test) }\end{array}$ & Two tailed $t$ test \\
\hline 0.30160 & 0.921 & 0.512 & 44.4 & Yes & $\begin{array}{r}\mathrm{t}(7)=2.47, \\
p=3.95 \mathrm{E}-06\end{array}$ \\
0.611120 & 0.975 & 0.685 & 29.8 & Yes & $\begin{array}{r}\mathrm{t}(7)=2.31, \\
p=3.73 \mathrm{E}-06\end{array}$ \\
\hline
\end{tabular}

Table 12 Summary of dust control efficiency for the CAC 10-in. height underneath the canopy using Medium Fan \#2

\begin{tabular}{lllllr}
\hline $\begin{array}{l}\text { Velocity } \\
(\mathrm{m} / \mathrm{s} \text { lfpm) }\end{array}$ & $\begin{array}{l}\text { Average canopy-off ratio } \\
\text { (canopy/upwind) }\end{array}$ & $\begin{array}{l}\text { Average canopy-on ratio } \\
\text { (canopy/upwind) }\end{array}$ & $\begin{array}{l}\text { Dust } \\
\text { reduction } \\
(\%)\end{array}$ & $\begin{array}{l}\text { Statistically significant } \\
\text { (Wilcoxson rank sum test) }\end{array}$ & Two tailed $t$ test \\
\hline 0.30160 & 0.878 & 0.539 & 38.6 & Yes & $\begin{array}{r}\mathrm{t}(3)=3.18, \\
p=1.28 \mathrm{E}-04\end{array}$ \\
0.611120 & 1.032 & 0.674 & 34.6 & Yes & $\begin{array}{r}\mathrm{t}(3)=3.18, \\
p=0.005\end{array}$ \\
\end{tabular}

illustrate how it was determined if there was a trend between supplied airflow and dust reduction.

These graphs compare the individual trials that were run when testing the CAC dust reduction efficiency. A total of
13 trials were completed. Trend lines are plotted to show the relationship of air supplied to the plenum versus percent dust reduction. While there seems to be a trend of increasing dust control efficiency when increasing the 
Table 13 Summary of dust control efficiency for the CAC at 10-in. height underneath the canopy using Large Fan \#3

\begin{tabular}{lllllr}
\hline $\begin{array}{l}\text { Velocity } \\
(\mathrm{m} / \mathrm{s} \text { lfpm) }\end{array}$ & $\begin{array}{l}\text { Average canopy-off ratio } \\
\text { (canopy/upwind) }\end{array}$ & $\begin{array}{l}\text { Average canopy-on ratio } \\
\text { (canopy/upwind) }\end{array}$ & $\begin{array}{l}\text { Dust } \\
\text { reduction } \\
(\%)\end{array}$ & $\begin{array}{l}\text { Statistically significant } \\
\text { (Wilcoxson rank sum test) }\end{array}$ & Two tailed $t$ test \\
\hline 0.30160 & 1.052 & 0.533 & 49.3 & Yes & $\begin{array}{r}\mathrm{t}(5)=2.57, \\
p=1.79 \mathrm{E}-4\end{array}$ \\
0.611120 & 0.998 & 0.563 & 43.6 & Yes & $\begin{array}{r}\mathrm{t}(7)=2.36, \\
p=3.57 \mathrm{E}-05\end{array}$ \\
\hline
\end{tabular}

Table 14 Average amount of air supplied to the plenum by fan type

\begin{tabular}{llll}
\hline Fan & Model & Blade & Airflow $\left(\mathrm{m}^{3} / \mathrm{slcfm}\right)$ \\
\hline Small Fan \#1 & AF-10 & Forward curved & 0.1621344 \\
Medium Fan \#2 & AF-10 & Forward curved & $0.184 \mid 390$ \\
Large Fan \#3 & AF15 & Radial & 0.2311490 \\
\hline
\end{tabular}

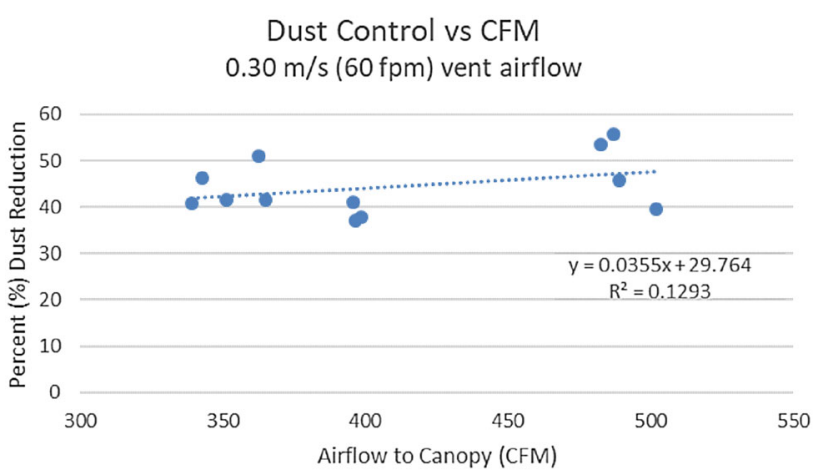

Fig. 8 Comparison of airflow to plenum to dust control efficiency of the $\mathrm{CAC}$ for the 60 -fpm entry ventilation airflow

airflow to the plenum, it is a weak relationship as seen by the $R^{2}$ values: $R^{2}=0.167$ for entry velocities of $0.3 \mathrm{~m} / \mathrm{s}$ $(60 \mathrm{fpm})$ and $R^{2}=0.462$ for entry velocities of $0.6 \mathrm{~m} / \mathrm{s}$ (120 fpm).

\section{Summary and conclusions}

The respirable dust reductions, measured $25.4 \mathrm{~cm}$ (10 in.) below the canopy air curtain, are presented in Table 15 . The range of dust reduction for this CAC is $29.8-49.3$ percent for nominal mine airflow velocities ranging from approximately $0.3-0.6 \mathrm{~m} / \mathrm{s}(60-120 \mathrm{fpm})$. The maximum dust control efficiency obtained at $25.4 \mathrm{~cm}(10 \mathrm{in}$.) was $49.3 \%$ with $0.3 \mathrm{~m} / \mathrm{s}(60 \mathrm{fpm})$ ventilation airflow. The results from this laboratory testing should advance NIOSH's goal that "Coal mine operators will adopt control interventions, such as technologies and work practices, to reduce overexposure to respirable coal mine dust," because they demonstrate that the roof bolter CAC can provide

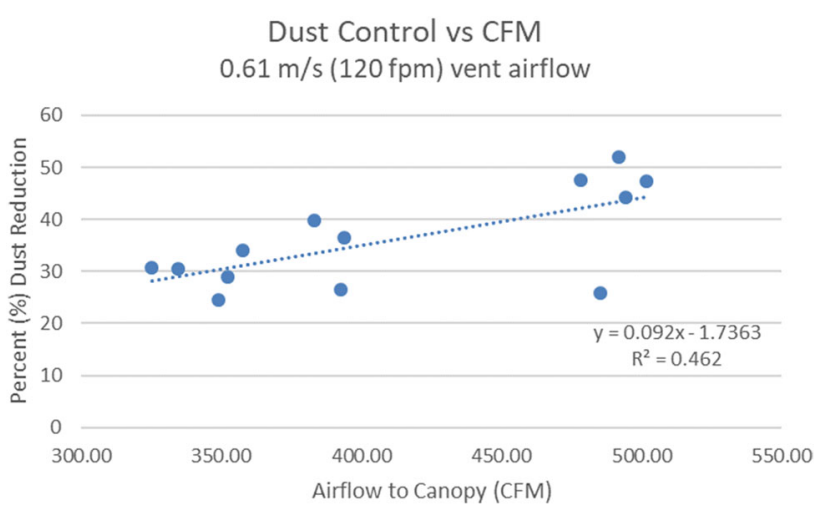

Fig. 9 Comparison of airflow to plenum to dust control efficiency of the CAC for the 120-fpm entry ventilation airflow

Table 15 Summary of dust control efficiency at $10 \mathrm{in}$. below the canopy air curtain

\begin{tabular}{lll}
\hline $\begin{array}{l}\text { Entry velocity } \\
(\mathrm{m} / \mathrm{slfpm})\end{array}$ & $\begin{array}{l}\text { Average Supplied } \\
\text { airflow }\left(\mathrm{m}^{3} / \mathrm{s} / \mathrm{cfm}\right)\end{array}$ & $\begin{array}{l}\text { Average respirable dust } \\
\text { reduction }(\%)\end{array}$ \\
\hline 0.30160 & 0.1621344 & 44.4 \\
0.30160 & 0.1841390 & 38.6 \\
0.30160 & 0.2311490 & 49.3 \\
0.611120 & 0.1621344 & 29.8 \\
0.611120 & $0.184 \mid 390$ & 34.6 \\
0.611120 & 0.2311490 & 43.6 \\
\hline
\end{tabular}

respirable coal mine dust protection for roof bolter operators.

A previously tested NIOSH-designed CAC showed $67 \%-75 \%$ dust control efficiency in airflows ranging from 0.05 to $0.61 \mathrm{~m} / \mathrm{s}(10-120 \mathrm{fpm})$ (Listak and Beck 2012). The NIOSH design attempted to produce a uniform air distribution pattern from the $\mathrm{CAC}$, which differs from the currently tested design.

The Fletcher-designed CAC has larger diameter holes than the NIOSH-designed CAC. Additionally, the Fletcher design utilizes high-velocity perimeter airflow while using low-velocity central airflow. This approach is intended to minimize intrusion of airborne dust carried by mine ventilation into the protected volume under the CAC. However, prior NIOSH testing showed that a homogenous air discharge from the CAC, as measured by air velocity 
profile, provides a higher measure of dust reduction. This 3rd generation Fletcher CAC has moved closer to the uniform airflow model. Field testing will ultimately prove the effectiveness of this 3rd generation CAC design.

Direct comparison to prior testing is complicated as this laboratory testing arrangement was different from the prior testing. Notable differences are that the dimensions of the testing area were larger than in prior testing, the distance from the dust source was shorter than in prior testing, and finally, the pathway of the airflow was considerably different than in prior testing, with the airflow having to make a U-turn rather than a $90^{\circ}$ turn as in the prior testing. These changes could have modified the airborne dust profile presented to the CAC, but the quantitative effects have not been analyzed. No additional lab testing of the roof bolter CAC is planned. The installation of many CAC on roof bolters in the field has changed the focus of CAC testing from the laboratory to field testing.

\section{Compliance with ethical standards}

Conflict of interest All authors have no competing interests in the research reported in this article.

Open Access This article is distributed under the terms of the Creative Commons Attribution 4.0 International License (http://crea tivecommons.org/licenses/by/4.0/), which permits unrestricted use, distribution, and reproduction in any medium, provided you give appropriate credit to the original author(s) and the source, provide a link to the Creative Commons license, and indicate if changes were made.

\section{References}

Blackley DJ, Crum JB, Halldin CN, Storey E, Laney AS (2016) Resurgence of progressive massive fibrosis in coal minersEastern Kentucky, 2016. Centers for Disease Control and Prevention, Morbidity and Mortality Weekly Report, vol 65, no 49, pp 1385-1389

Blackley DJ, Halldin CN, Laney AS (2018a) Am J Public Health. Published online ahead of print July 19, 2018, pp e1-e3. https:// doi.org/10.2105/ajph.2018.304517)
Blackley DJ, Reynolds LE, Short C, Carson R, Storey E, Halldin CN, Laney AS (2018b) Progressive massive fibrosis in coal miners from 3 clinics in Virginia. J Am Med Assoc Lett 319(5):500-501

Code of Federal Regulations, CFR 70.100 (2015) Code of Federal Regulations, 70.100 Respirable dust standards. CFR Title 30, Chapter I, Subchapter O, Part 70, Subpart B, 70.100., U.S. Government Printing Office, Washington, DC: National Archives and Records Administration

Colinet JF, Reed WR, Potts JD (2013) Impact on respirable dust levels when operating a flooded-bed scrubber in 20-foot cuts. NIOSH Report of Investigations 9683. IOSH Office of Mine Safety and Health Research, Pittsburgh, PA

European Communities Commission (1981) Studies of air curtain technology with particular application to the provision of clean air for underground workers. Final Report on ECSC research project 7251-17/8/085 (National Coal Board, Mining Research and Development Establishment)

European Communities Commission (1983) Application of air curtains and other methods for controlling ventilation and providing clean air at the workplace. Final Report on ECSC research project 7256-13/039/08 (National Coal Board, Mining Research and Development Establishment)

Goodman and Organiscak (2001) Laboratory evaluation of a canopy air curtain for controlling occupational exposures of roof bolters. In: Wasilewski S (ed) Proceedings of the 7th International Mine Ventilation Congress, June 17-22, 2001, Krakow, Poland. Research and Development Center for Electrical Engineering and Automation in Mining (EMAG), pp 299-305

Krisko WJ (1975) Develop and test canopy air curtain devices. USBM Contract Report HO232067, U.S. Department of the Interior, Bureau of Mines, Pittsburgh, PA/Donaldson Co. Inc.

Listak JM, Beck TW (2012) Development of a canopy air curtain to reduce roof bolters' dust exposure. Min Eng 64(7):72-79

Natrella MG (1963) Experimental statistics. National Bureau of Standards Handbook 91 (Washington, DC: US Dept. of Commerce, National Bureau of Standards)

Newman LS (eds) (2014) Silicosis. The Merck Manual Professional Version, Accessed at: http://www.merckmanuals.com/profes sional/pulmonary_disorders/environmental_pulmonary_dis eases/silicosis.html. Merck Research Laboratories

Potts JD, Reed WR, Colinet JF (2011) Evaluation of face dust concentrations at mines using deep-cutting practices. NIOSH Report of Investigations 9680 (Pittsburgh, PA: NIOSH Office of Mine Safety and Health Research)

Reed WR, Joy GJ, Kendall B, Bailey A, Zheng Y (2017) Development of a roof bolter canopy air curtain for respirable dust control. Min Eng 69(1):33-39 